\title{
Climate Change, Water Scarcity, and Health Adaptation in Southwestern Coastal Bangladesh
}

\author{
Md. Anwarul Abedin ${ }^{1}$ - Andrew E. Collins ${ }^{2} \cdot$ Umma Habiba $^{3} \cdot$ Rajib Shaw $^{4}$
}

Published online: 27 December 2018

(C) The Author(s) 2018

\begin{abstract}
Climate change may affect human health through multiple and interactive pathways that include safe water scarcity. However, impacts of climate change-induced water scarcity on health and well-being are complex. About $80 \%$ of illnesses in developing countries are attributed to unsafe drinking water and waterborne diseases. In Southwestern Bangladesh, lack of safe drinking water is a severe crisis due to climate change. The study investigated the impacts of climate change on water resources and human health in a coastal area. A questionnaire survey was carried out in two villages of Shymnagar upazila on the southwestern coast to investigate the present status of safe water sources and health care facilities and their impacts on the local community. The results show that the local community believes that climate change is having substantial impacts on freshwater sources and health. More than $70 \%$ of the respondents identified diarrhea, dysentery, and skin diseases as the prime waterborne health risks that occur through climate-related safe water scarcity. By synthesizing the ground data, we suggest pathways to health adaptation to climate change effects and safe water scarcity
\end{abstract}

Md. Anwarul Abedin

m.a.abedin@bau.edu.bd

1 Department of Soil Science, Bangladesh Agricultural University, Mymensingh 2202, Bangladesh

2 Department of Geography and Environmental Sciences/ Disaster and Development Network (DDN), Northumbria University, Newcastle upon Tyne NE1 8ST, UK

3 Department of Agricultural Extension, Ministry of Agriculture, Dhaka 1000, Bangladesh

4 Graduate School of Media and Governance, Keio University, Shonan Fujisawa Campus (SFC), Fujisawa, Kanagawa 252-0882, Japan through locally available adaptive practices such as the use of pond sand filters, rainwater harvesting, and importing potable water with the active participation of the government, nongovernmental organizations, and communities.

Keywords Climate change $\cdot$ Health risks $\cdot$ Safe water scarcity · Southwestern Bangladesh · Waterborne diseases

\section{Introduction}

According to the World Health Organization (WHO 2009), protecting health from the impacts of climate change is one of the defining challenges of the twenty-first century. Changes in precipitation and temperature and sea level rise are the climate factors that are expected to have consequences for the availability of freshwater around the world. Negative climate impacts on water resources are recognized as having adverse effects on human health. Inadequate water supplies for drinking, bathing, and farming are not only a current problem but also would accelerate difficulties for the world's growing population in the future.

The effects of climate change on both water and food security are the greatest negative human health impact in the developing world (Kovats et al. 2005; Costello et al. 2009). The Safe Drinking Water Foundation (SDWF 2018) highlighted that $80 \%$ of all illnesses in developing countries are attributed to unsafe drinking water and the spread of waterborne diseases. About 3 million people die from water-related diseases every year, the majority of whom are children under the age of five (DFID, EC, UNDP, and WB 2002). Shaw and Thaitakoo (2010) reported that approximately 1.1 billion people in the world do not have access to safe water. A safe, reliable, affordable, and easily 
accessible water supply is essential for healthy and prosperous survival (Hunter et al. 2010).

Bangladesh is experiencing climate change impacts through the consequences of the gradual rises of the sea level and temperatures, combined with increased regional climate variability and extreme events-that is more intense floods, droughts, and storms (Khan et al. 2011). These events are more prevalent in coastal areas because of sea level rise, poor rainfall in winter, high rates of evaporation, and various disastrous events like cyclones and storm surges. When disaster occurs, it affects water infrastructures and supply systems the most. Floods or tidal surges inundate tube wells, ponds, and water bodies and contaminate the natural sources of freshwater (WaterAid 2012). This situation is particularly distressing for the coastal population because they rely heavily on surface water (ponds and rivers) and groundwater (tube wells) for drinking (Khan et al. 2014). As a consequence, the coastal inhabitants are victims of an enduring crisis of water resources for drinking and domestic uses (Abedin et al. 2014). The crisis has increased with the incidence of waterborne diseases that are linked to sea level rise, floods, and salinity intrusion (Sikder and Jian 2014).

Climate change influences the rates of reproduction and survival of bacterial, protozoan, and viral pathogens and enhances the occurrence of conditions favoring the spread of waterborne diseases (DFID 2004). The risk of waterborne diseases such as diarrhea, cholera, and skin and eye diseases increases with the change of precipitation patterns that are likely to compromise the supply of freshwater through floods and waterlogging (BIRDEM 2012). The situation is alarming for the 20 million coastal people who are already facing increased exposure to diseases like hypertension because of the increased salinity of water (UNDP 2007). About 15 million people already are forced to drink saline water and 30 million people are unable to collect potable drinking water due to a lack of available safe water sources in coastal Bangladesh (Hoque 2009).

Although research in coastal areas of Bangladesh shows an impact of climate change on water resources (CCC 2009; IPCC 2007; Sharma and Sharma 2008; WHO 2008; Abedin et al. 2014), no work has been done so far on the impact of climate change on the water resources and human health of the coastal areas. Moreover, very few climate change-related projects that have been implemented by governmental organizations (GOs) or nongovernmental organizations (NGOs) have included local people as a focal point of the investigation of these issues. Because local people are the best overseers of local challenges and the different alternatives to solve them, this study attempted to involve local people by exploring their own examination of the effects of climate change on water resources and human health in the study area. This study also aimed to identify the suitable options of the local people in formulating a pathway for health adaptation strategies for coping with water scarcity as well as climate change in the context of coastal Bangladesh.

\section{Study Area}

The study area covers Shyamnagar upazila (subdistrict) of Satkhira District in the southwestern coastal region of Bangladesh (Fig. 1). Shyamnagar is located between $21^{\circ} 36^{\prime}$ and $22^{\circ} 24^{\prime}$ north latitudes and $89^{\circ} 00^{\prime}$ and $89^{\circ} 19^{\prime}$ east longitudes. It is a remote upazila in Satkhira District and is situated $50 \mathrm{~km}$ south of Satkhira City. The total population of the upazila is 313,781 (Banglapedia 2012). Fishing, agriculture, shrimp farming, salt farming, and tourism are the main economic drivers in this area. However, farmers in this area abandon agricultural lands because of increased soil and water salinity. We specifically studied the two villages of Durgabati and Gopalpur.

\subsection{Climatic Conditions}

The study area has a tropical monsoon climate with a high variation in monthly average temperatures. The annual average temperature is about $24.5^{\circ} \mathrm{C}$. The minimum temperature during winter can be as low as $8{ }^{\circ} \mathrm{C}$ whereas the maximum temperature can rise to as high as $35.5^{\circ} \mathrm{C}$. The humidity in this area is moderately high compared to the neighboring districts and shows high seasonal variation. It reaches its lowest level in March when rainfall is very low. With increasing rainfall, humidity increases gradually. A rapid increase in humidity occurs during May to August and at the end of August it decreases again (Fig. 2).

Annual rainfall in the study area shows a unique pattern of change. The amount of rainfall is very low during November to February. At the end of March rainfall increases and reaches its highest level during July. The least amount of rainfall occurs from the end of December to mid-January. Evaporation in the study area increases from January to May. At the end of May, the amount of evaporation decreases gradually up to the end of December and the evaporation is lowest in early January.

\subsection{Safe Drinking Water Situation}

The inhabitants of the southwestern coastal region are facing extreme difficulties in accessing safe drinking water (Swapan and Mamun 2006; Akber 2010). Nonavailability of drinking water is one of the most crucial and urgent problems in this area. Compared to past years, the people in Satkhira District experienced the highest level of suffering from drinking water shortages after the 2009 Cyclone Aila 


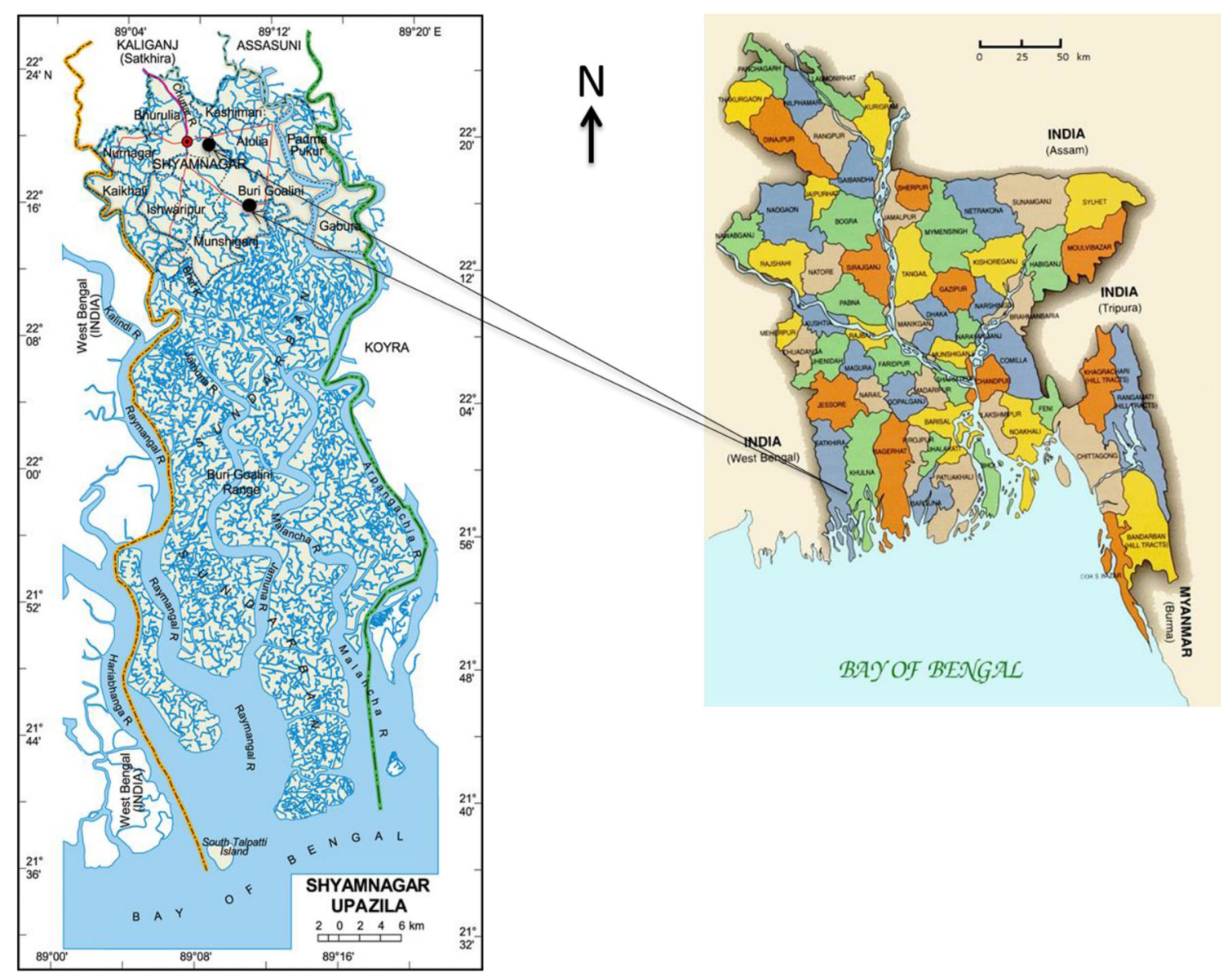

Fig. 1 Study area location in southwestern coastal Bangladesh: Durgabati and Gopalpur villages (black dots) in Shyamnagar upazila (subdistrict) of Satkhira District. Source: The Bangladesh country map is adapted from http://www.maps-of-the-world.net/

(Dasgupta et al. 2011). The water supply situation deteriorated in 12 unions of Shyamnagar upazila in Satkhira District because of the damage to over 2006 protected ponds, 158 pond sand filters, and 966 tube wells. Many people were forced to drink polluted water because they did not have any other options. As a consequence they suffered from various waterborne diseases such as allergies, skin diseases, cholera, and diarrhea. In extreme cases, waterborne diseases wreak havoc on victims.

Depending on the availability of safe water access ${ }^{1}$ and health care facilities, two villages-Durgabati from Burigoalini union and Gopalpur from Shymnagar union of Shyamnagar upazila - were selected as the specific study areas (unions are the smallest rural administrative and local government units in Bangladesh). In these two villages of Shyamnagar upazila, people have adjusted their livelihood pattern according to the quality and quantity of water available. In Durgabati village, which is closer to the coastal embankment and situated at the edge of

\footnotetext{
${ }^{1}$ Safe water access is defined as the availability of at least $20 \mathrm{~L}$ of water per person per day from an improved water source within a distance of $1 \mathrm{~km}$ of the user's dwelling (WHO and UNICEF 1990).
}

Shyamnagar upazila, the scarcity of freshwater is more acute to meet safe drinking water demand. In Gopalpur village, access to safe drinking water sources is available due to less saline water intrusion. The people of Gopalpur village also have easy access to the upazila health complex, whereas access to the upazila health complex is completely absent for the Durgabati villagers as this village is situated in the periphery of the upazila (Table 1).

\section{The Study Approach}

The depth and extent of the problem related to climate change, water scarcity, and the health impacts on households were conceptualized through literature review and preliminary field investigation. A questionnaire was prepared in accordance with the objectives of the study. The questionnaire focused on questions related to people's perceptions of climate change and its impact on different sectors, the causes of safe water scarcity, the source and supply of water, the extent of waterborne diseases, the access to health care facilities, and the expected coping measures. 



Fig. 2 Climatic conditions of the study area in southwestern Bangladesh. Source: Bangladesh Meteorological Department (http://bmd.gov.bd/)

Table 1 Selected villages in the study area based on safe water access and health care facilities

\begin{tabular}{llll}
\hline Name of the district & Name of the Upazila (Subdistrict) & Name of the union & Name of the village \\
\hline Satkhira & Shyamnagar & Durgoalini & $\begin{array}{l}\text { Durgati } \\
\text { (Safe water access and health care facilities are not available) } \\
\end{array}$ \\
& Shymnagar & $\begin{array}{l}\text { Gopalpur } \\
\text { (Safe water access and health care facilities are available) }\end{array}$
\end{tabular}

The study was carried out from September to November 2017. Systematic random sampling techniques were adopted to select the households. A total of 120 questionnaires (60 questionnaires from each village) were collected in the two study villages. The questionnaire survey was conducted by the first author with the assistance of trained university students. The respondents gave their responses by recalling their experiences with climate change, safe water scarcity, and health impacts. The collected data were summarized and carefully analyzed.

\section{Results and Discussion}

After collecting data through questionnaire survey, the data were analyzed. The results are discussed in the following subsections.

\subsection{Perceptions of Climate Change and its Effects on Different Sectors}

"Climate change" is a familiar term to the local people in the study area. The majority of the respondents in both villages stated that present climatic conditions have changed compared to the last 25-30 years. They recognized remarkable changes in temperature, precipitation pattern, salinity intrusion, scarcity and availability of water, and spread of various infectious diseases that are directly or indirectly related to climate. However, all of the respondents in Durgabati village, and $80 \%$ and $68 \%$, respectively, in Gopalpur village, agreed that increasing temperature and decreasing precipitation are the major climatic changes in the study area (Fig. 3).

Changes in temperature and precipitation, combined with changes in the frequency and intensity of extreme hydrometeorological events, have widespread implications 




Fig. 3 Climatic changes and the major impacts observed in the two study villages of southwestern coastal Bangladesh

for water resources that affect the supply, quality, and distribution of water resources for billions of people (Kundzewicz et al. 2007). The survey results confirm this problem-all of the respondents in both villages observed that water scarcity and availability is the most prevalent impact that arises from climatic changes (Fig. 3).

Higher water temperatures, increased precipitation intensity, and longer periods of low flows exacerbate many forms of water pollution, with impacts on ecosystems, human health, and the reliability and operating costs of water systems. Therefore, the respondents were asked about the major sectors where climate change impacts have been observed. All of the respondents in both villages stated that freshwater and health are the sectors most affected by climate change in the two study villages (Fig. 4).

\subsection{Climatic Causes of Safe Drinking Water Scarcity}

This section outlines the climatic causes of water scarcity in the study area that limit the availability of safe drinking water. All of the respondents in both villages indicated that the high salinity in surface and groundwater is primarily due to climatic causes and exacerbates safe drinking water scarcity in the two study villages (Fig. 5). This finding is in line with the Ministry of Environment and Forest,
Bangladesh (2005). Dankelman et al. (2008) stated that salinization of drinking water sources is becoming a major problem with increasing climatic variability. This crisis is more severe in some coastal villages in the southwestern region of Bangladesh where surface water salinity has increased alarmingly to as high as 15 parts per thousand (ppt), which is above the Food and Agriculture Organization (FAO) allowable drinking water limit of $<0.5 \mathrm{ppt}$ (Khan et al. 2011). Jakobsen et al. (2002) highlighted that water salinity in the coastal areas of Bangladesh varies from 0 to 20 ppt. Faisal and Parveen (2004), Alam (2003), IPCC (2001), and the World Bank (2000) have argued that water salinity and its distribution in the coastal areas are increasing with sea level rise.

Almost all respondents in Gopalpur village observed that lack of rainfall during the dry season, high salinity in surface and groundwater, and high temperature impede access to safe drinking water (Fig. 5). In Durgabati village, high salinity in surface and groundwater and heavy precipitation during the wet season cause unavailability of safe drinking water. These findings are in agreement with Manton et al. (2001), according to whom decreased precipitation and increased temperature, commonly associated with ENSO, have been reported to increase water shortages, particularly in parts of Asia where water resources are already under stress from growing water demands and inefficient water use. 
Fig. 4 Climate change effects on various sectors in the two study villages of southwestern coastal Bangladesh

Fig. 5 Climatic causes of safe drinking water scarcity in the two study villages of southwestern coastal Bangladesh
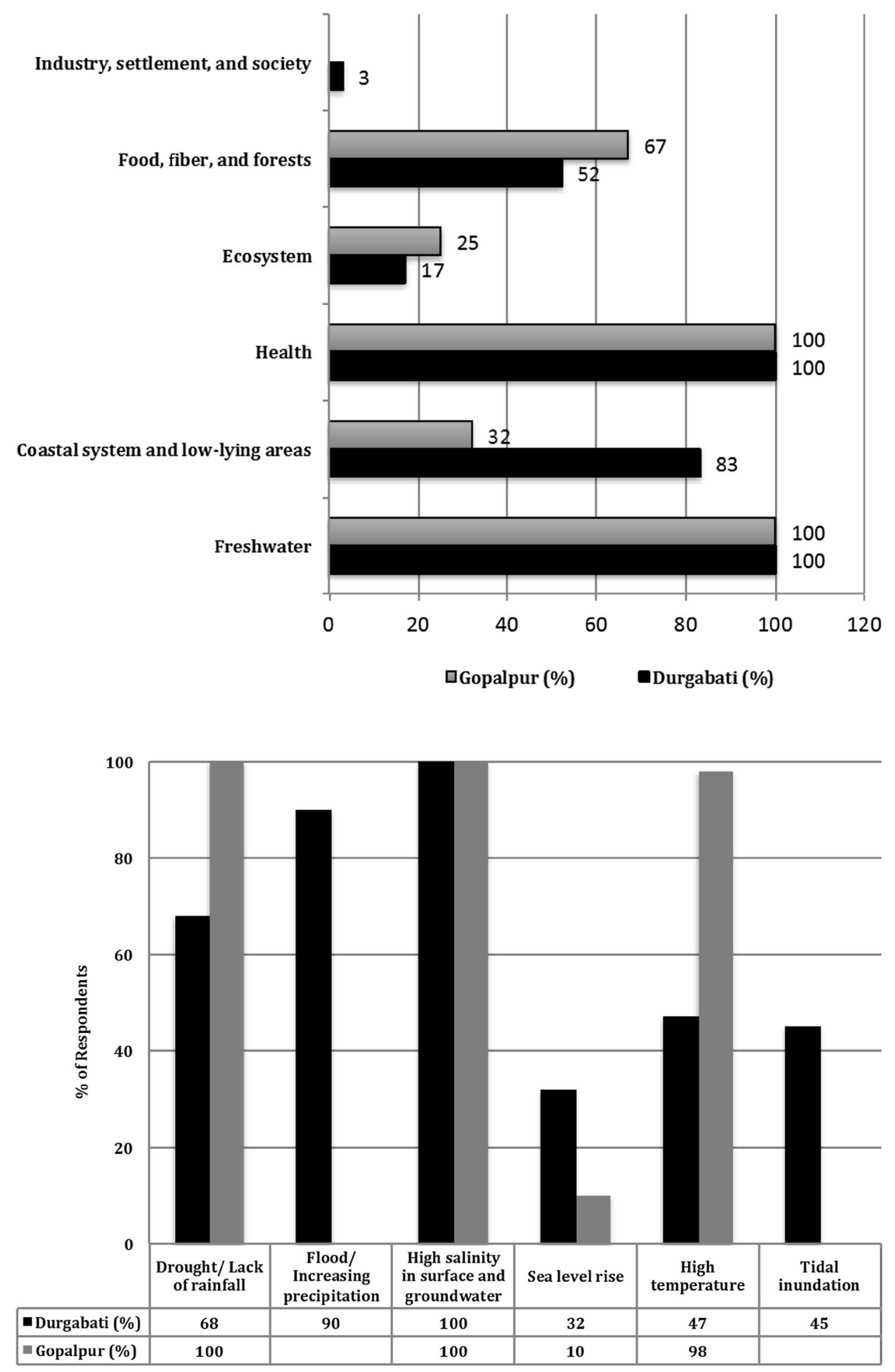

\subsection{Climate Change-Induced Water-Related Diseases}

As water scarcity is increasing worldwide, water-related diseases are increasing, especially in developing countries (Hunter et al. 2010). A recent study in India showed that domestic water scarcity is strongly associated with various kinds of health damage caused by infectious diseases (Motoshita et al. 2011). Increased flooding as well as drought result in a decline in the availability of clean water. In Bangladesh, waterborne diseases are already responsible for $24 \%$ of all deaths (Reid and Sims 2007). Increased 
Fig. 6 Waterborne diseases in the two study villages of southwestern coastal Bangladesh

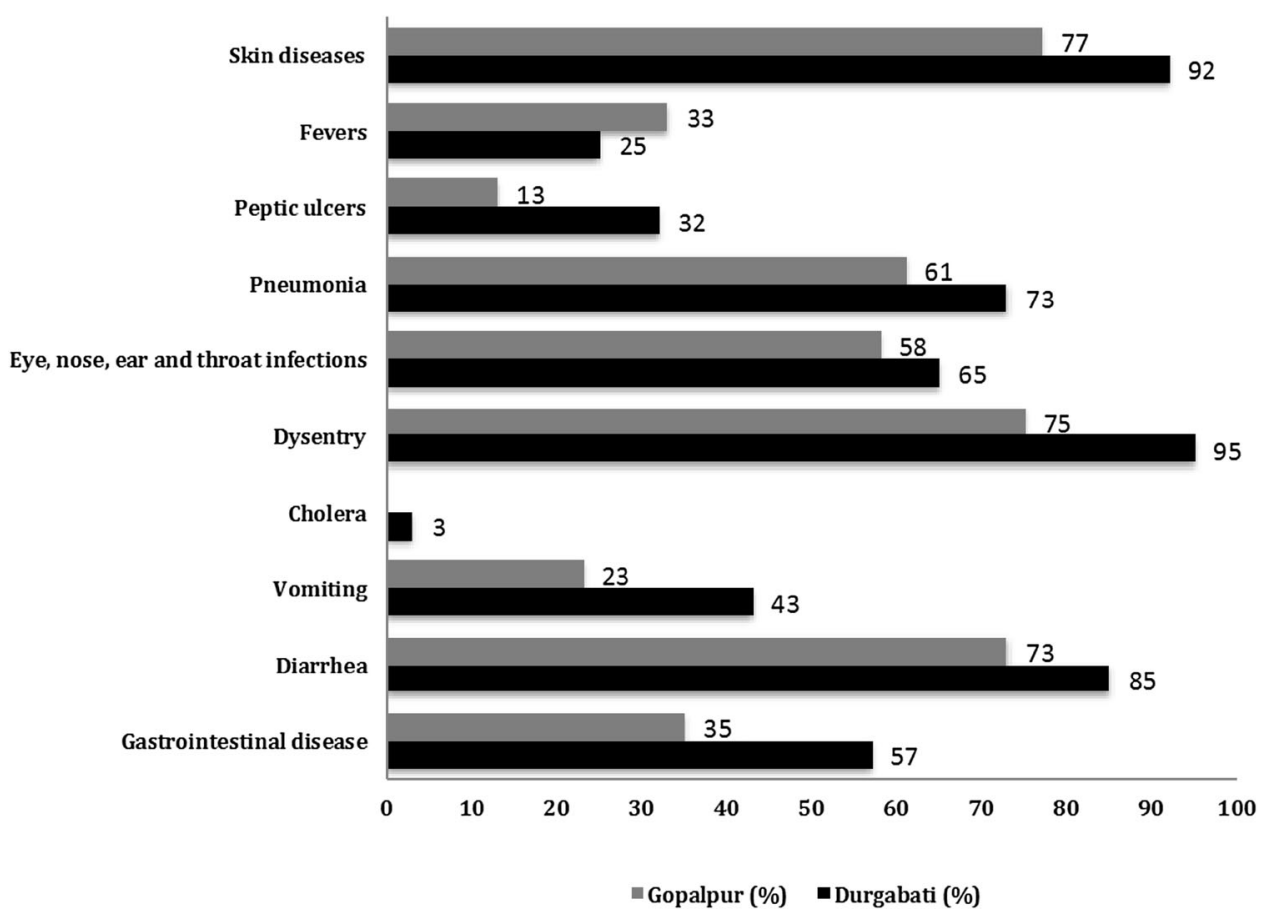

\subsection{Nexus of Climate Change, Water Scarcity, and Health}

Climate change plays a key role in safe water availability and scarcity and health-human health is the most important issue related to water quality. The impacts of climate change-including predicted increases in extremes - are likely to add to the stress, leading to additional pressure on water availability, accessibility, supply, and demand. Due to the very large number of people that may be affected, malnutrition and water scarcity may be the most important health consequences of climate change (IPCC 2007). In many parts of the world, water scarcity results in inadequate access to safe drinking water and this can lead to the spread of infectious diseases through fecal contamination of drinking water (waterborne diseases), such as typhoid and salmonellosis (Howard and Bartram 2003; Motoshita et al. 2011). Taking into account the effects of climate change on water resources, lack of safe drinking water poses a great risk for human health through various waterborne diseases. Figure 7 shows the overall causes and impacts of safe water scarcity on human health, induced by climate change effects.

\subsection{Water Supply and Distribution}

The entire Shyamangar upazila is facing a severe drinking water crisis. Ponds with pond sand filters and rainwater harvesting at household and community levels are the only major sources of safe drinking water. The survey results 
Fig. 7 Nexus of climate change, safe water scarcity, and health problems
Fig. 8 Sources of drinking water in the two study villages of southwestern coastal Bangladesh

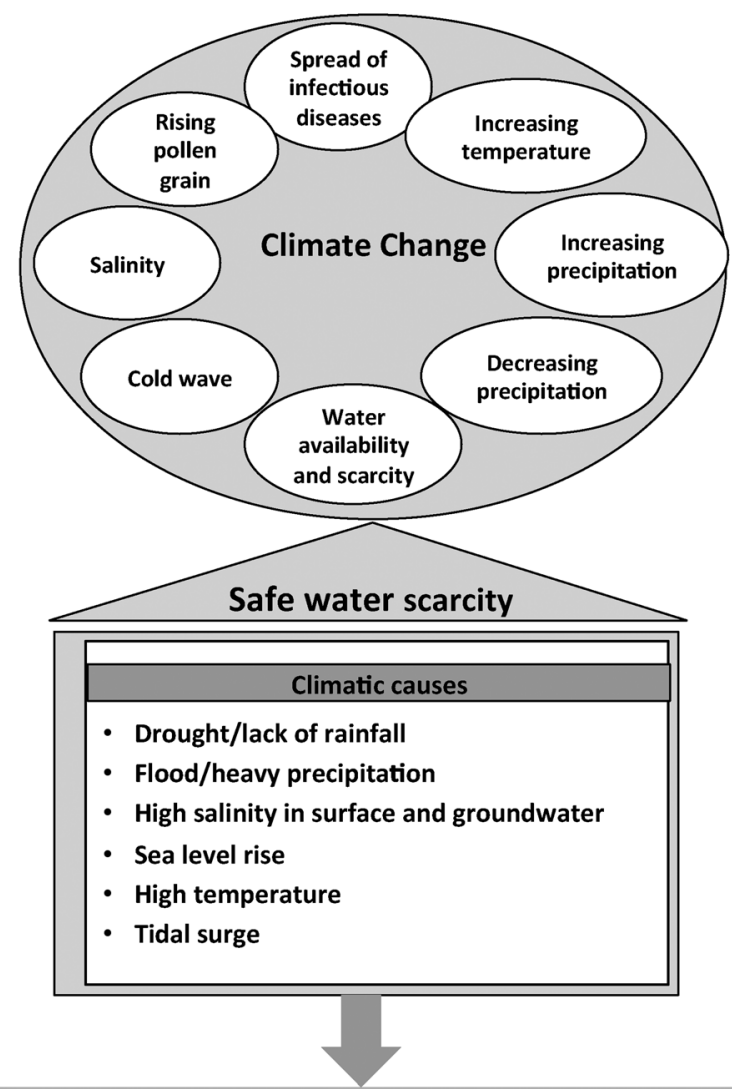

Health problems through waterborne diseases

(Skin diseases, fever, peptic ulcers, pneumonia, eye, nose, ear and throat infection, dysentry, cholera, vomiting, diarrhea, gastrointestinal diseases)

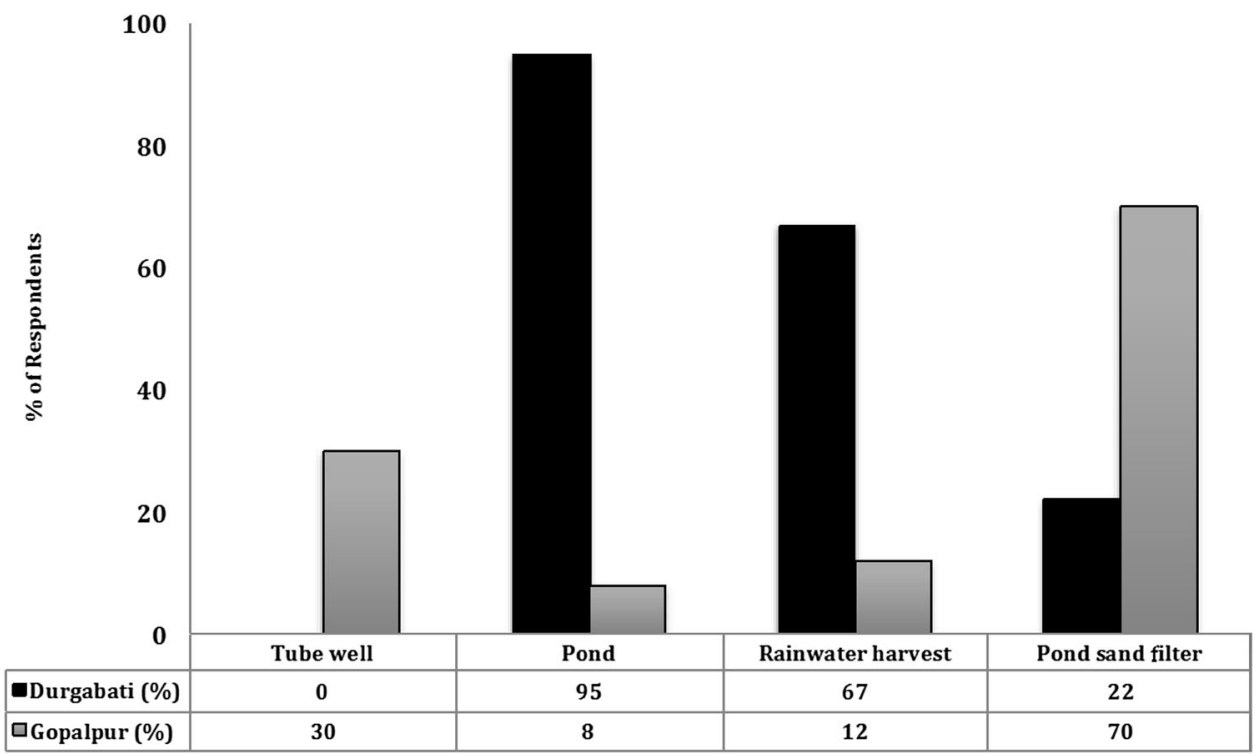

confirm the findings by Dasgupta et al. (2011). Pond sand filters provide the major year-round drinking water sources for $70 \%$ of the respondents in Gopalpur village (Fig. 8). The villagers also use tube wells, rainwater harvest, and ponds for drinking purposes, but the percentage is low compared to pond sand filters. The majority (95\%) of the respondents in Durgabati village use ponds as a source of drinking water due to lack of safe drinking water sources during the dry season. However, they boil the pond water before drinking. Moreover, $67 \%$ of the respondents in 
Fig. 9 Daily water requirement (liters per family) in the two study villages of southwestern coastal Bangladesh



Fig. 10 Distance inhabitants of the two study villages of southwestern coastal Bangladesh travel for collecting safe drinking water

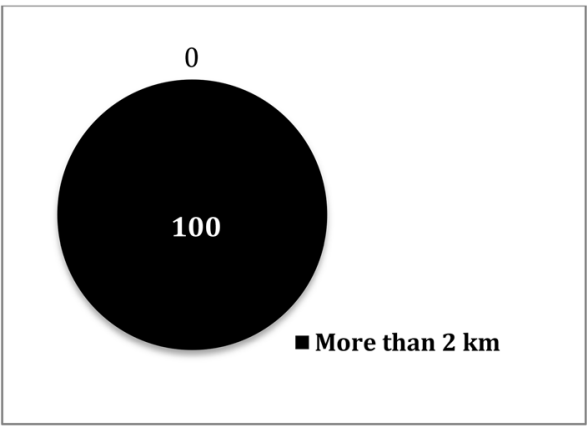

Durgabati village $(\%)$



Gopalpur village (\%)
Durgabati village employs the rainwater harvest method for drinking purposes, mostly during the rainy season and to some extent during the dry season.

The respondents in both villages were also asked about their daily water requirements (Fig. 9). More than half $(55 \%)$ of the respondents in Durgabati village indicated that they needed 25-30 L of water per day per family, whereas $50 \%$ of the respondents in Gopalpur village indicated they needed 31-35 L per day per family.

To meet the drinking water demands, the respondents collect safe drinking water from farther away. All respondents in Durgabati village fetch drinking water from locations more than $2 \mathrm{~km}$ away (Fig. 10). In extreme cases, women from some villages of southwestern coastal Bangladesh walk 6 to $12 \mathrm{~km}$ in order to fulfill the daily water requirement of three jars (one jar contains 12-15 L of water) per household (Swapan and Mamun 2006). More than two-thirds of the respondents (69\%) in Gopalpur village fetch drinking water from 0.5 to $1 \mathrm{~km}$, respectively.
Only $5 \%$ of the respondents in Gopalpur village have drinking water sources in their homestead.

The majority of the respondents in both villages indicated that housewives are the main collectors to fetch safe drinking water from nearby sources (Fig. 11). Next to housewives, $77 \%$ of the school going girls in Gopalpur village are also responsible for collecting safe drinking water, and $58 \%$ of the household heads in Durgabati village perform that task.

\subsection{Water Testing by Various Institutions}

To cope with safe drinking water scarcity, different water treatment options and alternative strategies like tube wells, rainwater harvesting, pond sand filters, and ponds are adopted by the end users with the assistance of GOs and NGOs. To assess the drinking water quality, various NGOs periodically check the drinking water quality of different water sources. A number of water tests such as color, total dissolved solids (TDS), $\mathrm{pH}$, salinity, $\mathrm{Cl}^{-}$, dissolved oxygen 
Fig. 11 Water collectors in the two study villages of southwestern coastal Bangladesh

Fig. 12 Performance of water quality tests in the two study villages of southwestern coastal Bangladesh

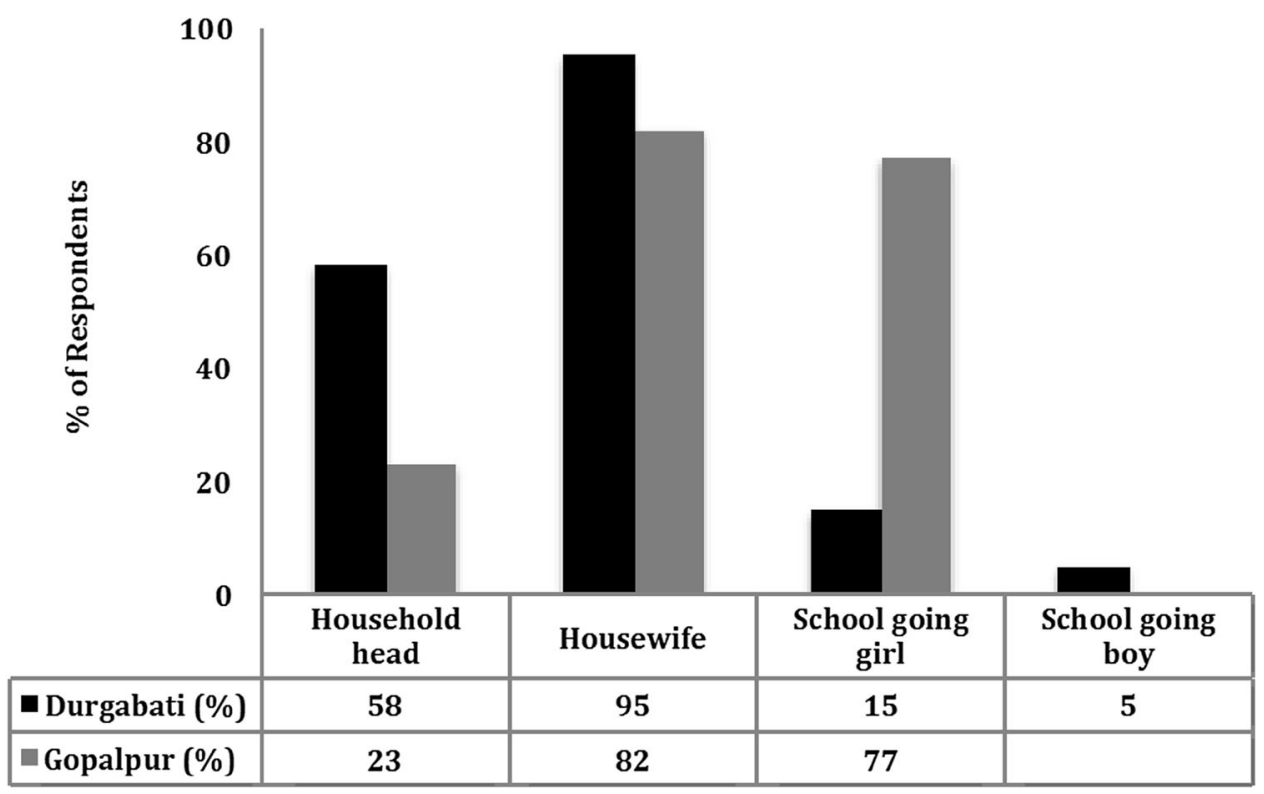

(DO), Hardness $\mathrm{K}^{+}, \mathrm{Ca}^{2+}, \mathrm{Mg}^{2+}, \mathrm{NO}_{3}{ }^{-}, \mathrm{SO}_{4}{ }^{2-}, \mathrm{PO}_{4}{ }^{3-}$, and Fecal coliform (no./100 ml) have been done to detect various water parameters, with the financial support of international funding agencies as well as governmental structures, namely the Department of Public Health Engineering (DPHE) in Bangladesh.

Results from the study area reveal that only salinity and arsenic tests are performed to check whether the water is safe for the people to drink or not. Figure 12 shows that $93 \%$ and $82 \%$ of the respondents in Gopalpur village stated that arsenic and salinity tests are done by BRAC (national NGO) and Sushilan (local NGO), respectively. More than half of the respondents in Gopalpur village indicated that the water quality test (both arsenic and salinity) is performed in their area on a monthly basis. Very little water testing has been done in Durgabati village.

\subsection{Adaptation Measures to Cope with Climate- Induced Waterborne Diseases}

Adaptation can greatly reduce vulnerability to climate change by making rural communities better to adjust against climate change and variability, moderating potential damages, and helping them to cope with adverse consequences (IPCC 2001). Adaptation reduces vulnerability and increases resilience. A good adaptation strategy gives the highest priority to the needs of local communities, valuing their knowledge. For implementing any adaptation 
Table 2 Suitable measures against water scarcity and health problems in the two study villages of southwestern coastal Bangladesh

\begin{tabular}{llcc}
\hline Serial Number & Measures taken by the respondents & Durgabati (\%) & Gopalpur (\%) \\
\hline 1 & Personal water filter & 15 & 42 \\
2 & Piped water supply & 18 & 15 \\
3 & Purchase of potable water & $\mathbf{9 3}$ & $\mathbf{7 5}$ \\
4 & Rainwater harvesting & 28 & $\mathbf{8 5}$ \\
5 & Pond sand filter & 32 & 43 \\
6 & Periodical medical check & 3 & - \\
7 & Temporary migration during dry period & 42 & 15 \\
8 & Balanced use of water & - & - \\
9 & Monitoring disease spread through TV/newspaper & 12 & 8 \\
10 & Stocking of water in advance & 2 & 18 \\
11 & Changes in food pattern (for example, use water succulent food) & 28 & \\
\hline
\end{tabular}

Top three adaptation measures are highlighted in the table using bold option

program it is very important to know the intensity of the problem and the probable solutions. Considering safe water scarcity, water supply, distribution, and their impact on human health, this section examines effective adaptive measures of the respondents that help to cope with the safe drinking water crisis and health risks.

\subsubsection{Measures for the Provision of Safe Drinking Water}

To deal better with water scarcity, the respondents in both villages were asked about their suitable adaptive measures. Table 2 shows that $93 \%$ of the respondents in Durgabati village recommended rainwater harvesting as the most suitable option to cope with safe drinking water scarcity, whereas pond sand filters were favored by $85 \%$ of the respondents in Gopalpur village. In addition, $75 \%$ of the respondents in Gopalpur village indicated that the purchase of potable water is another suitable option to get safe drinking water that will help to prevent various waterborne diseases.

\subsubsection{Health Care Facilities}

The coverage areas of upazila health complexes are very limited and most communities are far away from these complexes. This means that, in addition to the nonavailability of adequate health care facilities locally, affected people are not able to visit health complexes, union health centers, and community clinics. For these reasons, affected people are compelled to receive treatment from their nearby village doctors (indigenous medical practitioners). Based on the survey results, Fig. 13 shows the availability of health care facilities for the two study villages. Due to the relatively short distance to Shyamnagar upazila, the
Fig. 13 Availability of health care facilities to the inhabitants of the two study villages of southwestern coastal

Bangladesh




Table 3 Challenges of the respondents to implement adaptive practices in the two study villages of southwestern coastal Bangladesh

\begin{tabular}{llll}
\hline Serial number & Challenges of the respondents & Durgabati (\%) & Gopalpur (\%) \\
\hline 1 & Poor social cohesion in the community & 15 & 18 \\
2 & Lack of governmental as well as other organizational support & 72 & 75 \\
3 & Very poor economic conditions & 50 & 35 \\
4 & Very far distances to safe drinking water sources & 92 & 57 \\
5 & Social unrest & 3 & 20 \\
\hline
\end{tabular}

majority of the respondents $(82 \%)$ in Gopalpur village use the health care facilities of the upazila health complex to recover from various waterborne diseases. Being located far from upazila health complex, $68 \%$ of the respondents in Durgabati village depend on village doctors.

\subsection{Challenges to Implementing Suitable Adaptive Measures at the Household Level}

Although a number of adaptive measures are practiced in the study area, in terms of pond sand filters, the greatest challenge is to find suitable ponds that are perennial, free from pisciculture, and protected from use for bathing and washing clothes, watering cattle, and so on. The water for the pond sand filter process comes from ponds that may easily be contaminated and are pathways of waterborne diseases. Therefore, it is important that measures are implemented to protect the ponds from any source of contamination. About Tk 125,000 (USD 1500) are needed to establish a pond sand filter (Ishwaripur Development Foundation 2018).

With respect to rainwater harvesting, collecting water is sometimes difficult because of the dependence on the rainfall availability, with rainfall distribution varying widely across the country. Annual rainfall in the northeastern part of the country is about $5500 \mathrm{~mm}$, whereas in the southwestern part, it is around $1700 \mathrm{~mm}$. Water collected from thatched house rooftops is not safe, but the collection of rainwater from polythene sheet covered thatched rooftops is safe (Rana 2006). Most of the rainfall occurs from July to October in Bangladesh (for only 4 months). For the rest of the year, households have to depend on the stored rainwater using earthen or plastic pots. Hence, if the harvesting system is not maintained properly, and water is preserved for a long time, it may be affected by different types of bacteria or insects. Moreover, establishment cost of a rainwater harvesting facility for an individual household is prohibitive. Therefore, the main drawbacks of rainwater harvesting are the potential for microbial contamination and the high cost of storage sufficient for Bangladesh's 8-month dry season.

Apart from rainwater harvesting and pond sand filters, the purchase of potable water is safe for drinking.
Potable water comes from water purification plants (reverse osmosis, modern water filtration plants, and so on) with the support of international agencies and NGOs at the cost of Tk 0.40 per liter ( 1 USD $=82$ Taka). People who can afford it can collect this purified potable water using plastic jars. However, the number of people using this option is limited because of the availability of various other safe water supply sources and the economic conditions of the respondents in the study area (Farhana 2011).

Table 3 shows other challenges of the respondents that hinder them in the implementation of adaptive measures against water scarcity and health problems. More than $70 \%$ of the respondents in both villages claim that governmental as well as other organizational support is absent. Although the government has undertaken various activities as part of the water supply program throughout the country under different government policies and plans, implementation of any program that exclusively covers safe drinking water and health adaptation in the southwestern coastal region is absent. In Durgabati village, $92 \%$ of the respondents also reported that safe water sources are located very far from the respondents' houses, which is another barrier to collecting water.

\subsection{Stakeholder Involvement in the Execution of Safe Drinking Water Supply and Health Adaptation}

Drinking water is relevant in most of the Sustainable Development Goals (WHO and UNICEF 2017) because water is central to health and development. It is very possible to bring drinking water to everyone with prioritizing, planning, and funding, with stakeholder participation and with government providing services. Stakeholder involvement in drinking water access and supply for improving drinking water safety is crucial for the successful management and improvement of the drinking water supply system. Water and health development and management should be based on a participatory approach, involving users, planners, and policymakers at all levels.

To mobilize any practice or approach not only requires active participation of communities, but also needs feedback and support from various stakeholders such as 
governmental agencies, NGOs, and other organizations. It is imperative that communities' adaptation methods be supported and guided by local governments and NGOs to make them both more effective and environmental friendly (Parvin et al. 2008). At the same time, it is urgent to have efficient partnerships, collaboration, and coordination between government organizations and NGOs (Habiba et al. 2011). Therefore, before promoting any safe drinking water options towards health adaptation, these options should be tested at the community level and assessed in terms of acceptability, affordability, and accessibility for the user. Because communities would bear the responsibility for proper operation and maintenance, without their participation water options may rapidly fail. The respondents in both villages highlighted that community, NGO, and government involvement are all imperative to carrying out any suitable safe drinking water practices to prevent health problems.

\section{Conclusion}

By 2025, 1.8 billion people will be living in countries or regions with absolute water scarcity, and two-thirds of the world population could be under conditions of water stress, below the threshold for meeting the water requirements for agriculture, industry, domestic purposes, energy, and the environment (UN Water 2007). In Bangladesh, the management of water resources has become a crucial issue because of the growing demand for water and the increasing conflict over its alternative uses. As population increases and makes various uses of water, growing water scarcity is becoming a serious issue in Bangladesh.

The results of this study reveal that climate change poses a great risk for safe water availability and health problems in the study area. Safe drinking water as well as freshwater resources are badly hampered by the effects of climatic variability, such as salinity intrusion, drought during the dry season, and floods during the wet season. As a result, an overwhelming majority of the people is struggling to get safe drinking water and among them, more than $50 \%$ are affected by various health-related problems through waterborne diseases. However, safe drinking water measures and health care facilities are inadequate compared to demand, as the existing number of limited health centers shows. Households collect safe water from far distances. Considering all these issues, this research identified suitable safe drinking water practices-such as rainwater harvesting, pond sand filters, and potable water supplies-that are effective for securing safe drinking water. These practices ultimately help to adapt to health problems and to reduce waterborne diseases. To harmonize dealing with the challenges, this research underlines the role of multiple stakeholders (GOs, NGOs, and communities) in carrying out various adaptive actions toward safe drinking water and improved health.

Acknowledgements The first author acknowledges the support from the Bangladesh Agricultural University Research System (BAURES) to conduct this research.

Open Access This article is distributed under the terms of the Creative Commons Attribution 4.0 International License (http://crea tivecommons.org/licenses/by/4.0/), which permits unrestricted use, distribution, and reproduction in any medium, provided you give appropriate credit to the original author(s) and the source, provide a link to the Creative Commons license, and indicate if changes were made.

\section{References}

Abedin, M.A., U. Habiba, and R. Shaw. 2014. Community perception and adaptation to safe water scarcity: Salinity, arsenic and drought risks in coastal Bangladesh. International Journal of Disaster Risk Science 5(2): 110-124.

Akber, M.F. 2010. The water crisis. Dhaka, Bangladesh: The Daily Star. 3 May 2010. http://www.thedailystar.net/newDesign/newsdetails.php?nid_136756. Accessed 11 Jan 2018.

Alam, M. 2003. Bangladesh country case study. National Adaptation Programme of Action (NAPA) Workshop, 9-11 September 2003, Bhutan.

Banglapedia. 2012. Shyamnagar Upazila. http://en.banglapedia.org/ index.php?title=Shyamnagar_Upazila. Accessed 20 Nov 2018.

BIRDEM (Bangladesh Institute of Research and Rehabilitation for Diabetes, Endocrine and Metabolic Disorders). 2012. Health effects of climate changes in Bangladesh. Birdem Medical Journal 2(2): 75-76.

CCC (Climate Change Cell). 2009. Climate change and health impacts in Bangladesh. Department of Environment, Ministry of Environment and Forests, Bangladesh. http://ngof.org/wdb_new/ sites/default/files/Climate_Change_and_Health\%202009.pdf. Accessed 12 Dec 2017.

Checkley, W., L.D. Epstein, R.H. Gilman, D. Figueroa, R.I. Cama, J.A. Patz, and R.E. Black, 2000. Effects of El Niño and ambient temperature on hospital admissions for diarrhoeal diseases in Peruvian children. The Lancet 355(9202): 442-450.

Costello, A., M. Abbas, A. Allen, S. Ball, S. Bell, R. Bellamy, S. Friel, N. Groce, et al. 2009. Managing the health effects of climate change. The Lancet 373(9676): 1693-733.

Dankelman, I., K. Alam, A. Khurshid, W.B. Ahmed, Y.D. Gueye, N. Fatema, and R.M. Kutin. 2008. Gender, climate change and human security: Lessons from Bangladesh, Ghana and Senegal. Report prepared for the Hellenic Foundation for European and Foreign Policy (ELIAMEP). Prepared by the Women's Environment and Development Organization (WEDO) with ABANTU for Development in Ghana, Action Aid Bangladesh, and Environment and Development Action in the Third World (ENDA) in Senegal. http://www.gdnonline.org/resources/ WEDO_Gender_CC_Human_Security.pdf. Accessed 3 Feb 2018.

Dasgupta, S., B. Laplante, S. Murray, and D. Wheeler. 2011. Exposure of developing countries to sea-level rise and storm surges. Climatic Change 106(4): 567-579.

DFID (Department for International Development). 2004. Water action plan. A DFID policy paper. London: DFID. 
DFID (Department for International Development), EC (European Commission), UNDP (United Nations Development Programme), and WB (World Bank). 2002. Linking poverty reduction and environmental management: Policy challenges and opportunities. Washington, DC: World Bank.

Faisal, I.M., and S. Parveen. 2004. Food security in the face of climate change, population growth and resource constraints: Implications for Bangladesh. Environmental Management 34(4): 487-498.

Farhana, S. 2011. Suitability of pond sand filters as safe drinking water solution in storm surge prone areas of Bangladesh: A case study of post-Aila situation in Shyamnagar, Satkhira District, Khulna. Master's thesis. Postgraduate Programs in Disaster Management (PPDM), BRAC University, Dhaka, Bangladesh.

Habiba, U., R. Shaw, and Y. Takeuchi. 2011. Drought risk reduction through a socio-economic, institutional and physical approach in the northwestern region of Bangladesh. Environmental Hazards 10(2): 121-138.

Hoque, R.M. 2009. Access to safe drinking water in rural Bangladesh: Water governance by DPHE. Master's Thesis, Institute of Governance Studies, BRAC University, Dhaka, Bangladesh.

Howard, G., and J. Bartram. 2003. Domestic water quantity, service level and health. Geneva: World Health Organization. http://triplehelix blog.com/2011/03/unnecessary-and-deadly-the-post-disaster-cata strophe-of-waterborne-diseases/. Accessed 7 Dec 2017.

Hunter, P., A. MacDonalds, and R. Cater. 2010. Water supply and health. PLOS Medicine 7(11): 1-9.

IPCC (Intergovernmental Panel on Climate Change). 2001. Climate change 2001: Impacts, adaptation and vulnerability: Summary for policymakers. Contribution of Working Group II to the fourth assessment report of the Intergovernmental Panel on Climate Change. Cambridge: Cambridge University Press.

IPCC (Intergovernmental Panel on Climate Change). 2007. Climate change 2007: Mitigation. Contribution of Working Group III to the third assessment report of the Intergovernmental Panel on Climate Change. Cambridge: Cambridge University Press.

Ishwaripur Development Foundation. 2018. Installation of pond sand filter in southwest of coastal Bangladesh. Shymnagar, Satkhira, Bangladesh.

Jakobsen, F., M.H. Azam, and M.M.U. Kabir. 2002. Residual flow in the Meghna Estuary on the coastline of Bangladesh. Estuarine, Coastal and Shelf Science 55(4): 587-597.

Khan, A., P.F. Scheelback, A.B. Shilpi, Q. Chan, S.K. Mojumder, A. Rahman, A. Haines, S. Kovats, and P. Vineis. 2014. Salinity in drinking water and the risk of (pre)eclampsia and gestational hypertension in coastal Bangladesh: A case-control study. PLOS One 9(9): Article e108715.

Khan, A.E., W.W. Xun, H. Ahsan, and P. Vineis. 2011. Climate change, sea-level rise, \& health impacts in Bangladesh. Environment: Science and Policy for Sustainable Development 53(5): 18-33.

Kovats, R.S., D. Campbell-Lendrum, and F. Matthies. 2005. Climate change and human health: Estimating avoidable deaths and disease. Risk Analysis 25(6): 1409-1418.

Kundzewicz, Z.W., L.J. Mata, N.W. Arnell, P. Döll, P. Kabat, B. Jiménez, K.A. Miller, T. Oki, et al. 2007. Freshwater resources and their management. In Climate change 2007: Impacts, adaptation and vulnerability. Contribution of Working Group II to the fourth assessment report of the Intergovernmental Panel on Climate Change, ed. M.L. Parry, O.F. Canziani, J.P. Palutikof, P.J. van der Linden, and C.E. Hanson, 173-210. Cambridge: Cambridge University Press.

Lama, J.R., C.R. Seas, R. León-Barúa, E. Gotuzzo, and R.B. Sack. 2004. Environmental temperature, cholera, and acute diarrhoea in adults in Lima, Peru. Journal of Health, Population and Nutrition 22(4): 399-403.
Manton, M.J., P.M. Della-Marta, M.R. Haylock, K.J. Hennessy, N. Nicholls, L.E. Chambers, D.A. Collins, A. Gdaw, et al. 2001. Trends in extreme daily rainfall and temperature in Southeast Asia and the South Pacific: 1961-1998. International Journal of Climatology 21: 269-284.

Ministry of Environment and Forest, Bangladesh. 2005. National adaptation program of action. Dhaka: Ministry of Environment and Forest, Government of the People's Republic of Bangladesh.

Motoshita, M., N. Istsubo, and A. Inaba. 2011. Development of impact factors on damage to health by infectious diseases caused by domestic scarcity. International Journal of Life Cycle Assessment 16(1): 65-73.

Parvin, G.A., F. Takahashi, and R. Shaw. 2008. Coastal hazards and community-coping methods in Bangladesh. Journal of Coastal Conservation 12(4): 181-193.

Rana, S. 2006. Rain water harvesting for drinking in rural area. In Proceedings of MEDA Water International Conference on Sustainable Water Management, 21-24 March 2007, Tunis Tunisia. https://www.ctahr.hawaii.edu/hawaiirain/Library/ papers/Rana_Md.Sohel.pdf. Accessed 15 Nov 2018.

Reid, H., and A. Sims. 2007. Up in smoke? Asia and the Pacific. Up in Smoke Working Group on Climate Change and Development. https://www.oxfam.ca/sites/default/files/file_attachments/mil lions-of-vulnerable-people-in-asia-bearing-the-brunt-of-climatecrisis-says-new-report_2.pdf. Accessed 11 Jan 2018.

SDWF (Safe Drinking Water Foundation). 2018. Water and human health. https://www.safewater.org/fact-sheets-1/2017/1/23/ water-and-human-health. Accessed 11 Nov 2018.

Sharma, S., and J. Sharma. 2008. A study of stress \& cope-up strategies of service sector employees. Indian Management Studies Journal 12: 19-35.

Shaw, R., and D. Thaitakoo. 2010. Water communities: Introduction and overview. In Water communities, ed. R. Shaw, and D. Thaitakoo, 1-13. Bingley, UK: Emerald Publishers.

Sikder, R., and X. Jian. 2014. Climate change impact and agriculture of Bangladesh. Journal of Environment and Earth Science 4(1): $35-40$.

Singh, R.B.K., S. Hales, N. de Wet, R. Raj, M. Hearnden, and P. Weinstein. 2001. The influence of climate variation and change on diarrhoeal disease in the Pacific Islands. Environmental Health Perspectives 109(2): 155-1594.

Swapan, S.S.A., and Md. M. Mamun. 2006. In search of safe drinking water: In the context of climate change and salinity. Satkhira, Bangladesh: Uttaran and Water Committee. (English version of the Bangladeshi monograph, translated by A.R. Quazi.) https:// uttaran.net/publications/insearchofsafedrinkingwater.pdf. Accessed 11 Dec 2018.

UN Water. 2007. Coping with water scarcity: Challenge of the twenty-first century. Prepared for World Water Day 2007. http:// www.unwater.org/wwd07/downloads/documents/escarcity.pdf. Accessed 23 Mar 2007.

UNDP (United Nations Development Programme). 2007. Human development report. Country fact sheets: Bangladesh.

Uzzaman, M.A. 2014. Impact of sea level rise in the coastal areas of Bangladesh: A macroeconomic analysis. Journal of Economics and Sustainable Development 5(18): 105-109.

WaterAid. 2012. Handbook on climate change and disaster resilient water, sanitation and hygiene practices. Dhaka, Bangladesh: Wateraid in Bangladesh.

WHO (World Health Organization). 2008. Guidelines for drinkingwater quality. Geneva: WHO.

WHO (World Health Organization). 2009. Protecting health from climate change: Global research priorities. Geneva: WHO.

WHO (World Health Organization) and UNICEF (United Nations Children's Fund). 2017. Progress on drinking water, sanitation and hygiene: 2017 update and SDG baselines. Geneva: WHO 
and UNICEF. https://www.who.int/mediacentre/news/releases/ 2017/launch-version-report-jmp-water-sanitation-hygiene.pdf. Accessed 17 Dec 2018.

WHO (World Health Organization), and UNICEF (United Nations International Children's Emergency Fund). 1990. Joint
Monitoring Programme for Water Supply and Sanitation. http://www.wssinfo.org/en/122_definitions.html. Accessed 18 Nov 2018.

World Bank. 2000. Bangladesh: Climate change and sustainable development. Report No. 21104 BD. Dhaka: World Bank. 